RATKO DUEV

UDC: $2-264(=11 /=2)$

Faculty of Philosophy

University of Ss. Cyril \& Methodius in Skopje

ratko.duev@gmail.com

\title{
SOME THOUGHTS ON THE INDO-EUROPEAN SUPREME GOD
}

\begin{abstract}
Comparative analyses indicate that many attributes of the Indo-European thunder-gods are reminiscent of those of Zeus. There are some notable differences, however, which preclude the sky-god and storm-god from being equated. The Indo-European Dye eus is not a supreme god, but that role is assumed by the storm-god. The only reflection of the Sky Father in Greek and Roman religion is the king of the gods, but as a thunder-god. The supremacy among the gods in the Indo-European Pantheon cannot be tied to heaven alone, as suggested by comparative analyses of German mythology and their sovereign god Wodan/Odin.
\end{abstract}

1. There is a problem in science in determining the supreme god of the Indo-Europeans. The notion of ${ }^{*} D y \bar{e} u s$ as the supreme god ${ }^{1}$ is primarily related to the supreme gods derived from the same root: Zeus in the Greek Pantheon, and Jupiter in the Roman. The Greek Zeus is the king of the gods, and supreme god, whose power extends to all spheres of life, yet in the divine world of the Rgveda, Dyáuš has no such role. He is the father of the gods, but not their king. Only six hymns are named after him, ${ }^{2}$ and those are always in relation to the earth. The Indo-European Sky Father is a divine entity that resembles deus otiosus ${ }^{3}$ in that he can roar and thunder ${ }^{4}$. Although his rain is the seed that fertilizes the earth, ${ }^{5}$ Indra is the chief storm-god.

${ }^{1}$ Т. В. Гамкрелидзе, Вяч. Вс Иванов, Индоевропейский язык и индоевропейцы. Реконструкции и историко-типологический анализ праязыка и протокультуры, том 1-2, Тбилиси 1984, 791s.; G. E. Dunkel, 'Vater Himmels Gattin,' Die Sprache 34/1, 1988-1990, p. 1-26.

${ }^{2}$ From the 1028 hymns of Rgveda.

${ }^{3}$ M. Eliade, Myth and Reality, New York 1963. The term originates from M. Eliade. Eliade designates a god-creator who gives the first impulse to creation and then withdraws from the further formation of the divine world, and has no role in mythology and religion, like Uranus in Greek mythology.

${ }^{4} R V$ 5. 58. 6; 10. 44. 8, 45. 4, 67. 5.

${ }^{5} R V$ 1. 100. 3; 5. 17. 3 . 
Comparative analyses with other Indo-European mythologies indicate that the storm-god is a special figure in the Indo-European pantheon and is not identified with the deified heaven. ${ }^{6}$ A number of classical philologists believe that the function of storms is tied to the great god of heaven, like Zeus in Greece and Jupiter in Rome. There are, however, other Indo-European mythologies in which thunder is not linked to a sky-god, such as the Hittite god Tarhunna, the Vedic god Indra, the old Slavic god Perun, the old Germanic god Donar or Thor, or the Celtic god Taranus or Taranis. Undoubtedly, the Indo-European tradition has developed a special thunder-god.

2. Comparative testimonies ${ }^{7}$ date chronologically from the Vedic Indra, who brings victory in battles, among other functions. ${ }^{8}$ Vedic hymns also mention other deities related to thunder, lightning, and rain, such as Maruts and Parjanya. Parjanya is called the son of Dyáuš, ${ }^{9}$ which shows his connection to heaven. ${ }^{10}$ In Rgveda, he is also portrayed as a lover of the earth, who fertilizes, replacing Dyáus,${ }^{11}$ and is especially associated with rain, as evidenced by the noun parjánya, meaning 'rain cloud'. The etymology of his name is most frequently associated with the Lithuanian Perkunas and the Nordic Fiorgynn, but the problem arises when trying to reconstruct ${ }^{*} P e r k^{w} u n(y) o-$, which, in fact, would form *Perkun(y)a-, while Sanskrit -jan-is associated with the root* -gan-/ gen-/ gon-. The challenge in reconstructing the singular Indo-European form is usually overcome by explaining the differences among Perun, Perkunas and Parjanya with the root *per,which can have different formats such as ${ }^{*} p e r-k^{w}$ and ${ }^{*} p e r-\hat{g}_{-}$, as well as the deformation to be explained by taboos in certain religions in terms of the pronounciation of the names of the gods. ${ }^{12}$ Another Vedic god is called the son of Dyáuš, ${ }^{13}$ Indra the king of the gods, ${ }^{14}$ who is associated with thunder but not rain like Parjanya, and is also sometimes

${ }^{6}$ Contrary to the thesis of Dunkel, that the Greek epithet of Zeus keraunos is from PIE * peraunos, and, in fact, not a separate deity but just a different attestation of the IE Sky Father, which can hardly be proved, see R. Duev, 'Zeus and Dionysus in the Light of Linear B Records', [in:] Colloquium Romanum, Atti del XII International Colloquium di Micenologia, Pasiphae 1-2, Pisa: Rome, 2008, 225s.

${ }^{7}$ They come from different periods, some of them, like the Lithuanian Perkunas, attested in $1300 \mathrm{AD}$, compares to the Hittite Tarhunna, whose testimonies date back to $1500 \mathrm{BC}$, meaning there is a time difference of approximately 2800 years.

${ }^{8}$ M. L. West, Indo-European Poetry and Myth, Oxford.2007, 244.

${ }^{9} R V$ 7. 102. 1.

${ }^{10}$ More broadly T. Oberlies, Die Religion des Rgveda, Erster Teil, Vienna 1998, 200ss.

${ }^{11} R V$ 5. 83. 4; 7. 101. 3.

${ }^{12}$ D. Dunkel (1988-1990, 3) explains problematically through the taboo deformation that goes beyond the valid philological explanation. Although, according to the functions, we may speak of similarity, Dunkel's purpose is not to identify or analyze the gods and their names, but rather the epithet of Zeus keraunos.

${ }^{13} R V$ 4. 17.4, 10. 120. 1.

${ }^{14} R V$ 1. 174. 1. Perhaps his name is linked with the Old Slavic *jẹdrŭ. 
portrayed as a bull, which has an even greater role in mythology. His most common epithet is vrtrahán-, 'destroyer', according to the myth of his victory over the demon Vrtráh ${ }^{15}$ who stopped the waters and was killed by Indra's thunder. From the same period in Anatolia, in the Hittite mythology in the Song of Kumarbi (or the 'Hittite Theogony'), there is also mention made of the god Tarhunna or Tarhunta, ${ }^{16}$ whose name is derived from the root *tarh-, meaning 'overcomes, victory,' however, the form *-u-no- is largely reminiscent of Perkunas and Perun. ${ }^{17} \mathrm{It}$ is noticeable that the myth is not a reflection of the Indo-European tradition, but rather an influence of the Hurrian thunder-god Teshub.

3. The thunder-god in Celtic Gaul and Britain is revered under the names of Taranis, Taranus, or Thanarus - Old Irish torann, Welsh taran 'thunder', and English 'Thunder,' originating from the theonym ${ }^{*} D u$ naraz, Old Norse Pórr, Old High Germanic Donar or Thunar, and we can connect with the Latin tonare, tonitrus, bearing the same meaning of 'thunder'. It may originally have been derived from the onomatopoeic word for thunder, and it is possible that the theonym ${ }^{18}$ may also be related to the name of the Anatolian thunder-god Tarhunna, with tarh root metathesis: *trh ${ }_{2} V n o->* t n h_{2} V r o-.{ }^{19}$ Since Old Norse literature is so well-preserved, the functions of the god Thor can be clearly evidenced, unlike the Celtic Donar or Taranis. Thor is not only a thunder-god, but also a controller of time, and fertility of the crops, a friend of man, and a protector against the forces of evil, for which he enjoys great reverence and popularity as a god. In Eda's poetry, he is the son of Fiorgyn, ${ }^{20}$ Earth (Iorð) and Odin, and is also associated with trees, as indicated by Swedish and Danish toponyms such as Thorslund, Torslunde, 'Thor's grove.' Furthermore, in Dublin he has an oak forest dedicated to him. ${ }^{21}$ His weapon is the great hammer, Miollnir, which he would thow at his victims, usually at creatures from beyond the human world, mostly giants. He also defeats the cosmic

15 The name means 'opponent, enemy' (cf. M. L. West 2007, 246).

${ }^{16}$ Luwian Tarhunza, Latvian Taru.

${ }^{17}$ G. Nagy, Greek Mythology and Poetics, Ithaca 1990, 189s.

${ }^{18}$ R. Jakobson, Selected Writings, vol. I-VIII, Hague: Paris 1962 -88, VII/7, 23; J. Puhvel, Comparative Mythology, Baltimore 1987, 169; J. de Vries, Altgermanische Religionsgeschichte, Berlin 1956, 113-153.

19 cf. F. Bader, La langue des dieux, ou l'hermétisme des poètes indo-européens, Pisa 1989 and M. L. West 2007, 249, n. 40.

${ }^{20}$ Her male counterpart Fiorgynn, probably an older deity of the storms, is perhaps related to Perkunas.

${ }^{21}$ More broadly J. Lindow, Norse Mythology: A Guide to the Gods, Heroes, Rituals, and Beliefs, Oxford University Press 2001, 287ss. Tacitus (Ann. 2: 12) also testifies for 'Thor's grove', in the description of the event (VI c. AD) when Germanicus crossed the Visurgis river into the territory of the Cherusci and confronted the army of Arminius who had been assembled in a forest dedicated to Hercules (Dunaraz). Zeus's son, Heracles, has recently been associated with the cult of the thunder-god (see more extensively M. L. West 2007, 249). 
creature Iormungand, or the Midgard serpent. Because of this feat, he is called orms einbani, 'serpent killer', which is compared to the $v r$ trahán epithet of the Vedic thunder-god Indra. ${ }^{22}$ The characteristics of the god Thor, which he shares with other Indo-European thunder-gods, are thunder being produced by the driving of a goat-drawn car across the sky. ${ }^{23}$

4. The Baltic thunder god is known as Perkūnas in Lithuania, and as Perkons in Latvia. ${ }^{24}$ Perkunas appears as a mythical figure in Lithuanian and Latvian folk songs, as well as in prayers to protect people's homes and crops, and to bring rain in dry periods. ${ }^{25} \mathrm{He}$ is most commonly portrayed as an anthropomorphic, scowling and bearded god who blazes, fire and throws his ax (or, more usually, a hammer), which returns to his hand. The Baltic tradition presents the god as a killer of devils, goblins, or the dragon Aitvaras. Perkons distinguishes himself from Perkunas by his weapons, such as a spear, sword, scepter, arrows, and stones. Perkunas' car is drawn by a goat, which is linked to the belief that an oncoming storm is heralded by a snipe, whose waving tail produces a goat-like sound when flying through the air, called 'the goat of God' or 'the goat of Perkunas'. ${ }^{26}$ The Baltic lightning is particularly associated with the oak tree, usually affected by lightning, and whose fire could be used by humans. There are holy oaks on which idols are set, Perkūno ą̌uolas, Pérkōnō ōzōls, the 'Oak of Perkunas'. ${ }^{27}$ This detail is very important for the etymology of the name derived as Perku-, compared to the Latin quercus 'oak', with the addition of the Indo-European suffix meaning 'Master of', hence the name Perku-nas would mean 'master of oaks'. ${ }^{28}$

5. In the Slavic tradition, the thunder god was the god Perun, whose name also means 'thunder' ${ }^{29}$ His significance in the Slavic religion can be attested through a series of documents originating from Kiev and Novgorod from the X century, as well as from the Byzantine historian Procopius, who mentions the cult of the 'maker of thunder' who was responsible for all things. ${ }^{30}$ Perun is depicted with a yellowish beard, perched high on the mountain or in the sky, from where he would

${ }^{22}$ Cf. M. L. West 2007, 250.

${ }^{23}$ Thor was a great eater and drinker, known for his big red beard.

${ }^{24}$ H. Usener, Götternamen: Versuch einer Lehre von der religiösen Begriffsbildung, Bonn 1896, 97; J. Puhvel, 'Indo-European Structure of the Baltic Pantheon,' in G. J. Larson (ed.), Myth in Indo-European Antiquity, University of California Press 1974, 75-86; M. L. West 2007, 239.

${ }^{25}$ In modern Lithuanian and Latvian, the words perkūnas and pērkons mean 'thunder'.

${ }^{26}$ M. L. West 2007, 240, n. 8.

${ }^{27}$ R. Jakobson 1962-1988, VII/17.

${ }^{28}$ Note that the Roman deity ${ }^{*}$ Quercūnus is not encountered.

${ }^{29}$ In modern Slavic languages, such as Russian peruny, Polish piorum, Czech peraun.

${ }^{30}$ Procop. Bell. Goth. 3. 14. 32. Cf. J. Puhvel 1987, 233 ss. 
throw his ax or shot at his victims. Like Perkunas, he is associated with the burning oak, but there are also sacred trees known as the 'Perun oak'. ${ }^{31}$ Perun's different suffix compared to the Baltic Perkunas is interpreted as a possible influence of taboo deformation, ${ }^{32}$ or the etymology may be deduced from the Old Slavic verb *per 'hits' and the suffix -unü (from *-ünos or *-aunos).

6. It is clear that a number of attributes of Indo-European thunder-gods are reminiscent of the attributes of Zeus, but there are some differences that do not allow the two functions, sky and storm-god, to be equated. The Indo-European supreme god is assumed by the stormgod, not Dyēus. The reflection of the Sky Father only in the Greek and Roman religions is the 'king of the gods', but as the thunder-god. Could that be because of early syncretism of the two functions, or is it due to the development of epithets in particular deities? Or, is there another reason? That the supremacy among the gods in the Indo-European pantheon cannot be tied to sky ${ }^{33}$ alone is also the comparative analysis with German mythology and their sovereign god Wodan/Odin. ${ }^{34}$ His name originates from *Wōðanaz, 'Lord of *wō ${ }^{*}$,' which means 'inspiration', and is poetic and divine, which can be etymologically linked to Latin vātes 'prophet, seer' and fäith 'poet, prophet'. ${ }^{35}$ Odin is the king of magic and can easily change his shape, most often to an eagle. He can blind and paralyze his enemies to lead him to victory, but unlike Thor, he has never been in battle. ${ }^{36}$ Odin is often represented as a oneeyed, elderly, bald man with a hat. As a sovereign, Odin is referred to in the poems as Alfogr, 'Father of all', and in the poem Eda and fadir allra godanna ok manna, 'father of all gods and men', ${ }^{37}$ as the formula in early Greek poetry where Zeus is patēr andrōn te theōn te. ${ }^{38}$ What is particularly noteworthy is the fact that the Indo-European root meaning 'sky' is found in another deity Týr, who is traditionally presented as the son of Odin or Hymir. ${ }^{39}$ His name is preserved in the

${ }^{31}$ R. Jakobson $1962-88$, VII / 17s. The connection of the oak with the thunderbolt is also witnessed in the Temple of Zeus in Dodona, and the famous oak forest from which the prophets received their visions (cf. and D. Evans, 'Dodona, Dodola and Daedala,' in G. J. Larson (ed.), Myth in Indo-European Antiquity, University of California Press 1974, 112).

${ }^{32}$ R. Jakobson $1962-1988$, VII/17s.

${ }^{33}$ Contrary to В. Гамкрелидзе and Вяч. Вс. Иванов (1984, 792s.), developed by G. E. Dunkel (1988-1990), which eliminates the uniqueness of the god of heaven and the god of storms.

${ }^{34}$ E. Polomé, 'Approaches to Germanic Mythology,' in G. J. Larson (ed.), Myth in Indo-European Antiquity, University of California Press 1974, 51-66; J. Lindow 2001,247 ss.

${ }^{35}$ Cf. M. L. West 2007, 34 and137: like 'madness'; E. Polomé 1974, 62.

${ }^{36}$ E. Polomé 1974, 62; linking some of his attributes with the Vedic Varuna.

${ }^{37}$ M. L. West 2007, 173, n. 29.

38 Possible doubt about this comparison is related to the influence of classical culture, such as Virgil's formula "hominum sator atque deorum" (Aen. 1. 254).

${ }^{39}$ J. Lindow 2001, 247ss. 
day Tuesday. ${ }^{40}$ A testimony to Odin's supremacy is also evident in the Roman historian Tacitus, who states that the Germans most respected Mercury, ${ }^{41}$ the Roman name for Odin.

This attestation of Mercury is particularly interesting, as it is also linked to Herodotus' information that the Thracian kings most respected Hermes, ${ }^{42}$ yet due to the scant data on the Thracian gods, it is difficult to identify the god in question. ${ }^{43}$ Herodotus is assumed to identify with the cult of the Thracian horseman, a chthonic deity, which must not be equated with Dionysus, as he also cites the gods Ares, Dionysus and Artemis. Hermes is the most complex deity in the Greek pantheon of many attributes; besides the basic function of a 'messenger of God', who crosses the boundaries between heaven and earth, he is a wizard and psykhopompos 'guide to the souls' of the dead in the underworld, ${ }^{44}$ similar to the basic functions of Odin, who are also taken over by the Romans in the cult of Mercury. Julius Caesar also cites 'Mercury' as the supreme deity of the Celts. In Slavic mythology, the identification of the supreme god is very difficult because there are so few records. The analysis of V. Čajkanovic on the primacy of a chthonic deity in the pantheon of Svetovid-Triglav offers a corollary, however, whose attributes are the same as those of Odin /Wodin, the Thracian horseman, and the Celtic Dispater. ${ }^{45}$ The Thracian horseman is most often accompanied by shadows of the dead, as well as Odin, so that he is not only a hunter, but also an incarnation of the belief in life after death, which points to his chthonic character. ${ }^{46}$ Between the Germans and the Slavs, their summus deus occurs in the theriomorphic forms of the wolf and horse, with the epiphany in the wolf more pronounced in the north of Europe, and the horse in the southeast of Europe. $^{47}$

7. From the above it may be concluded that there is no archetype for the IE supreme god. Although linguistic reconstructions influenced by Greek mythology are increasingly common, the testimony of ancient authors about the cunning character of the supreme god among individual Indo-European peoples must be seriously included. As

${ }^{40} \mathrm{Ibid}$. Tuesday is also thought to be related to Latin Dies Martis, and its proximity to dies is perceived in the plural form tivar, meaning 'gods'.

${ }^{41}$ Ger. 9; Cf. E. Polomé 1974, 61.

42 5. 7.

${ }^{43}$ R. Pettazzoni, 1955, 184ss.

${ }^{44}$ From 24. 1-15; cf. R. Duev 2006, 52.

45 В. Чајкановиќ, О српском врховном богу, Београд 1941, 166. The problem is that by analogy to the Greek and Roman thunder-god, the thunder-god Perun is considered to be the supreme god in the Slavic pantheon, or at least by the Western Slavs, by the analogy of Baltic Perkunas. However, there is no such image among the South Slavs.

${ }^{46}$ Ibid.

${ }^{47} \mathrm{Ibid}$. It is especially important that the Thracian horseman also appears as threeheaded. 
previously mentioned, diachronic methodology may draw conclusions that are indecisive; one must tend towards conclusions drawn from a synchronic methodology of researching the history of ancient cults and beliefs in the Aegean.

\section{BIBLIOGRAPHY}

Bader, F., La langue des dieux, ou l'hermétisme des poètes indo-européens, Pisa 1989.

Чајкановић, В., О српском врховном богу, Београд 1941.

Dexter, M. R., 'Dawn and Sun in Indo-European Myth: Gender and Geography,' Studia Indogermanica Lodziensia II, 1999, pp. 103-122.

Duev, R., 'Zeus and Dionysus in the Light of Linear B Records', [in:] Colloquium Romanum, Atti del XII colloquio internazionale di Micenologia, Pasiphae 1-2, Pisa: Roma, 2008, pp. 223-230.

Dunkel, G. E., 'Vater Himmels Gattin,' Die Sprache 34,1, 1988-1990, pp. 1-26.

Evans, D., 'Dodona, Dodola and Daedala,' in G. J. Larson (ed.), Myth in Indo-European Antiquity, University of California Press 1974.

Eliade, M., Myth and Reality, New York 1963.

Гамкрелидзе, Т. В., Иванов, Вяч. Вс., Индоевропейский язык и индоевропейцыь. Реконструкции и историко-типологический анализ праязыка и протокультуpbl, том 1-2, Тбилиси 1984.

Jakobson, R., Selected Writings, vol. I-VIII, Hague: Paris 1962-88.

Nagy, G., Greek Mythology and Poetics, Ithaca 1990.

Lindow, J., Norse Mythology: A Guide to the Gods, Heroes, Rituals, and Beliefs, Oxford University Press 2001.

Oberlies, T., Die Religion des Rgveda, Erster Teil, Vienna 1998.

Polomé, E., 'Approaches to Germanic Mythology,' in G. J. Larson (ed.), Myth in IndoEuropean Antiquity, University of California Press 1974, pp. 51-66.

Puhvel, J., 'Indo-European Structure of the Baltic Pantheon,' in G. J. Larson (ed.), Myth in Indo-European Antiquity, University of California Press 1974, pp. 75-86.

${ }^{48}$ The same can be observed when analyzing the cult of the sun god. For example, the Baltic peoples, Scandinavians and the Irish respect the Sun Goddess, and Greek, Romans and Indians - Sun God, (M. R. Dexter, 'Dawn and Sun in Indo-European Myth: Gender and Geography,' Studia Indogermanica Lodziensia II, 1999, 103122). The problem is whether the PIE deity of the sun was a goddess, and, under the influence of the male sun gods from other Mediterranean civilizations, became a sun god in Southeast Europe? Compared to this research, the most important fact is that the god Helios played a marginal role in the Greek Pantheon despite his clear IE etymology, and the connection to the epithets of the supreme god Zeus (cf. M. L. West 2007, especially 'Sun and Daughter,' pp. 194-237). Also of interest is the fact that the supreme god in the Etruscan pantheon was the god Tin or Tinia, but his thunder was shared with other gods. He is a young god, often portrayed as either a naked boy or a bearded man (N. Thomson de Grummond, E. Simon, The Religion of the Etruscans, Austin 2006, 45). The Etruscans were not Indo-Europeans, but an isolated example like the Minoans (at least according to current knowledge, although the IE theory of their origin and language has recently been reinforced). 
Puhvel, J., Comparative Mythology, Baltimore 1987.

Thomson de Grummond, N., Simon, E., The Religion of the Etruscans, Austin 2006. de Vries, J., Altgermanische Religionsgeschichte, Berlin 1956.

Usener, H., Götternamen: Versuch einer Lehre von der religiösen Begriffsbildung, Bonn 1896.

West, M. L., Indo-European Poetry and Myth, Oxford 2007. 